\title{
The Role of Universities in the Provision of Corporate Social Responsibility and Ethics Teaching in the Agricultural Sector
}

\author{
By Christopher Moon * \\ Joseph Gebbels ${ }^{\dagger}$
}

Previous studies such as Cornelius et al. (2007) have focused on the role of business schools in equipping their students with an understanding of Corporate Social Responsibility (CSR) and ethical reasoning skills. This study appears to be the first look at CSR and ethics teaching specifically within the agricultural sector. Given agricultures direct link between economics and the environment (Diebel 2008) and the public's growing perception that business is harming the environment (Porter and Kramer 2011) this study provides a timely insight into CSR and ethics teaching within agricultural education. By means of a content analysis of syllabuses from the top agricultural institutions in four English speaking countries-Australia, Canada, the UK and the USA this study has highlighted that despite the policy and cultural differences between countries that the level of CSR and ethics teaching in each of the countries does not significantly differ $(P>0.05)$. Furthermore and surprisingly, institutional ranking was also not found to have a significant effect $(P>0.05)$ on CSR and ethics teaching provision. This has important implications for academia, industry and the public alike.

Keywords: Agricultural Education, Agricultural Policy CSR (Corporate Social Responsibility), Environment, Ethics.

\section{Background}

Recent events have seen an increased focus on the role of business schools in the provision of corporate social responsibility (hereinafter CSR) and ethics teaching (Cornelius et al. 2007). There has however been comparatively little analysis of CSR and ethics teaching provision in other sectors.

The subject is of considerable interest to businesses as research has shown that the CSR and ethics which a company displays affects its financial performance (Zairi and Peters 2002, Fombrun and Shanley 1990). The public increasingly sees businesses as the cause of environmental degradation; (Porter and Kramer 2011) consumers have as a result become increasingly eco-aware and ethically conscious with regard to their purchasing habits (Wilson 2000).

This paper will focus specifically on the agricultural sector and CSR and ethics teaching in agricultural undergraduate courses.

\footnotetext{
${ }^{*}$ Senior Lecturer in Eco-Entrepreneurship, Middlesex University, UK.

${ }^{\dagger}$ Independent Industry Advisor, UK.
} 


\section{Agriculture, Economics and the Environment}

There is perhaps no clearer link between economics and the environment than the agricultural industry (Diebel 2008) and as such professionals in the industry face numerous moral and ethical dilemmas during their daily business practices (Lozano et al. 2006).

The industrialisation of agriculture and the economic pressures on the industry have created a new range of ethical challenges for producers (Hendrickson and Harvey 2005). Scholars such as Hendrickson and Harvey (2005) and Sagoff (1988) have drawn parallels between factors such as industrialisation, concentration of production, globalisation and the demands of transnational retailers and the erosion of ethical standards amongst agricultural producers. Zimdahl (2000) argues that without the provision of education to students who take-up a variety of positions within the industry, professionals within the industry will only be equipped to respond to ethical issues with defensive arguments in support of the paradigm of production.

These arguments fail to reveal the ethical foundations of the industry and inhibit the development of a greater understanding of the deeper moral issues that surround the industry (Zimdahl 2000). As Porter and Kramer (2011) discussed in the Harvard Business Review in 2011 society is increasingly blaming businesses for environmental degradation. Industry failure to proactively innovate and reduce environmental impacts means that governments create policies which enforce environmental protection, but also often stifle innovation and growth.

In order for the agricultural industry to regain control over the development of the industry and to play a part in the shaping of new values and ethical dimensions, the industry must recognise the opportunity and obligation to develop practices which deliver environmental sustainability alongside economic prosperity (Zimdahl 2000). In order to do so universities teaching students in the field need to analyse the provison of ethics and CSR teaching in their syllabuses and better equip students to deal with ethical challenges which they face in their careers (Zimdahl 2000).

\section{CSR and Ethics in Agriculture}

Agriculture faces a range of ethical challenges which other industries may not incur. The direct and constant link between the industries economic performance and the environmental conditions, means that producers have a responsibility to protect the environment both from an ethical and legal stand point (Diebel 2008). Producers must consider how their economic activities and the coinciding management procedures such as the use of chemicals, machinery and cultivations affect the environment. Furthermore, the production of livestock for milk, meat, eggs etc., also creates moral and ethical burdens (McEachern and Schroder 2001). For practical insights into the moral and commercial issues faced by companies in general see Moon and Bonny (2001). 


\section{Environmental Ethics and Responsible Land Utilisation}

Due to the direct link between environment and agriculture (Foley et al. 2003) the protection or degradation of the much of the environment is in the hands of agri-businesses globally. Around 35\% of land area globally is used for agriculture and urban areas (Foley et al. 2003). This figure is considerably higher in developed regions; in Europe $81 \%$ of land is utilised for forestry, agriculture, or urban areas (European Environment Agency 2010).

There are many examples of land degradation as a result of agricultural activity, for instance 400,000 hectares in South Australia are affected by elevated salinity as a result of agricultural practices (Goodman 2012). This has significant economic as well as environmental implications. Regulatory platforms and the risk of reputational damage are deterrents for the misuse and damage of the environment (Nguyen and Leblanc 2001). However, much degradation still occurs, particularly where regulatory platforms are poorly enforced (Goodman 2012).

Businesses must go beyond compliance with regulations and the avoidance of prosecution and instead seek elevated ethical stances, whereby more widereaching consideration is given to the implications of their practices outside of the commercial setting. Businesses must seek to respond to growing public disillusionment with corporate malfeasance if they are to be effective at capturing the purchasing power of increasingly eco-aware consumers (Cornelius et al. 2007, Fombrun and Shanley 1990, Wilson 2000).

\section{Research Objectives and Hypothesis Formulation}

\section{Country Comparisons}

This review focuses on four English speaking countries ${ }^{1}$ Australia, Canada, the UK and the USA. The primary objective is to compare and contrast the level of CSR and ethics teaching in agricultural education in these countries. Focusing on these four countries facilitates wide ranging applicability in the field.

Each of these countries has different legislative and market structures and each have significant divergences regarding environmental and agricultural policies. Thompson (2000) noted that there was far greater willingness to participate in international environmental agreements on the part of the Canadian government than the USA government. Furthermore, Thompson (2000) concluded that Europeans have more ethically coherent mind-sets than their American and Canadian counterparts. Such a divergence in perception, level of understanding and opinion is just one example of differences between the countries. Table 1 illustrates that there are also considerable differences in regulations and legal status of a variety of techniques.

\footnotetext{
${ }^{1}$ Due to similarities between regulatory systems of the UK and Ireland, the University of Dublin will be included with the UK sample. Also, because of similar regulatory requirements, Massey University in New Zealand will be included with the Australian sample.
} 
Table 1. Comparison of Legislative/Policy Standpoint

\begin{tabular}{|c|c|c|c|c|}
\hline Parameter & Australia & Canada & UK & USA \\
\hline $\begin{array}{l}\text { Legality of } \\
\text { genetically } \\
\text { modified } \\
\text { crops }\end{array}$ & $\begin{array}{l}\text { Legal-for a } \\
\text { limited } \\
\text { number of } \\
\text { crops }\end{array}$ & $\begin{array}{l}\text { Legal-for a broad } \\
\text { range of crops }\end{array}$ & $\begin{array}{l}\text { Largely } \\
\text { prohibited }\end{array}$ & $\begin{array}{l}\text { Legal-for a } \\
\text { broad range of } \\
\text { crops }\end{array}$ \\
\hline $\begin{array}{l}\text { Hormone use } \\
\text { for animal } \\
\text { production }^{3} \\
\end{array}$ & $\begin{array}{l}\text { Legal in } \\
\text { certain cases }\end{array}$ & $\begin{array}{l}\text { Legal in certain } \\
\text { cases }\end{array}$ & Prohibited & $\begin{array}{l}\text { Legal in certain } \\
\text { cases }\end{array}$ \\
\hline $\begin{array}{l}\text { Fallen stock } \\
\text { legislation }{ }^{4}\end{array}$ & $\begin{array}{l}\text { Various } \\
\text { options } \\
\text { including } \\
\text { burial and } \\
\text { incineration }\end{array}$ & $\begin{array}{l}\text { Various options } \\
\text { including burial } \\
\text { and incineration }\end{array}$ & $\begin{array}{l}\text { Government } \\
\text { approved } \\
\text { transport and } \\
\text { disposal }\end{array}$ & $\begin{array}{l}\text { Various options } \\
\text { including burial } \\
\text { and incineration }\end{array}$ \\
\hline $\begin{array}{l}\text { Greening } \\
\text { requirements }\end{array}$ & $\begin{array}{l}\text { Action plans } \\
\text { and } \\
\text { regulations } \\
\text { specifically } \\
\text { geared } \\
\text { towards: } \\
\text { - Water } \\
\text { conservation } \\
\text { and salinity } \\
\text { management }\end{array}$ & $\begin{array}{l}\text { Regulations } \\
\text { governing: } \\
\text { - Public health. } \\
\text { - Environmental } \\
\text { health. } \\
\text { - Biodiversity. } \\
\text { - Water and air } \\
\text { quality }\end{array}$ & $\begin{array}{l}\text { Include: } \\
\text { - Subsidised } \\
\text { environmental } \\
\text { schemes. } \\
\text { - } 7 \% \text { minimum } \\
\text { non-produ-ction } \\
\text { land. } \\
\text { - Maximum } \\
\text { 70\% of one } \\
\text { crop variety }\end{array}$ & $\begin{array}{l}\text { Include: } \\
\text { - Subsidised } \\
\text { environmental } \\
\text { conservation } \\
\text { schemes. } \\
\text { - Subsidised } \\
\text { bio-energy } \\
\text { production }\end{array}$ \\
\hline
\end{tabular}

Source: Prepared by Authors'.

It is important to note that the purpose of this section and table is not to provide a comprehensive comparison of the countries agricultural sectors, rather, the aim is to demonstrate that there are considerable differences in areas that have clear ethical dimensions. Hence:

- Hypothesis 1 - There will be significant differences in the level of ethics and CSR teaching provided to undergraduate students in the agricultural field as a result of differing geographical locations of the institutions.

2 Department of Agriculture (2013), Canadian Food Inspection Agency (CFIA) (2013), Department for Environment Food and Rural Affairs (DEFRA), (2013a), Qaim and Kouser (2013).

${ }^{3}$ Food Standards Australia and New Zealand (2011), Canadian Federal Department of Health (2012), United States Government Printing Office (2014).

${ }^{4}$ Gwyther et al. (2011), Ministry of Agriculture and Food (2009), Department for Environment Food and Rural Affairs (DEFRA) (2013b), American Meat Institute (2009).

5 Department of the Environment (2013a), Department of the Environment (2013b), Government of Canada (2010), Canadian Federation of Agriculture/Federation Canadienne De L'Agriculture (CFA) (2007), House of Commons Environment, Food and Rural Affairs Committee (HCEFRA) (2012), Organisation for Economic Co-operation and Development (OECD) (2011). 


\section{Analysis of Rankings}

The seconday objective of the study is to determine if higher ranking agricultural schools have a higher level of CSR and ethics teaching inclusion in their syllabuses.

As such it was noted that Cornelius et al. (2007) found that top tier business schools displayed proactive ethics inclusion in contrast to their lower ranked counterparts who were more likely to display reactive ethics in their syllabuses. Based on these findings it is assumed that the higher ranking institutions in the sample will include a higher level of CSR and ethics teachings in their syllabuses than their lower ranked counterparts. Hence:

- Hypothesis 2 - The top fifty institutions will have a higher level of ethics and CSR teachings in their syllabuses than the bottom one hundred institutions in the sample regardless of geographic location of the institutions.

\section{Methodology}

The aim of this analysis is to analyse the incorporation of CSR and ethics teaching in agricultural undergraduate courses in institutions in each of the four subject countries.

In order to analyse the CSR and ethics teaching in each of the individual institutions, the syllabuses of final year undergraduate students (undertaking a BSc in Agricultural Science or similar) were analysed using a mix of quantitative and qualitative methods. Syllabuses provided a good source of data as they are presented in a relatively similar fashion by each institution and they provide an accessible relevant means of accessing content information.

\section{Data Set-Institution Selection}

To identify institutions which provide undergraduate courses in Agricultural Science (or similar) in one of the subject countries the Quacquarelli Symonds (QS) world university rankings system was utilised (QS 2013); only institutions ranked in the top 200 in the field globally were included.

Furthermore, only the institutions whose syllabuses (i.e., individual module descriptors) were freely available were included in the analysis; institutions offering <10 modules/minors in the final year of study were omitted as were institutions who only provide postgraduate courses.

Once the above selection variables had been applied to the QS top 200 list a total of 47 relevant institutions were selected (Figure 1). 
Figure 1. Number of Institutions per Country

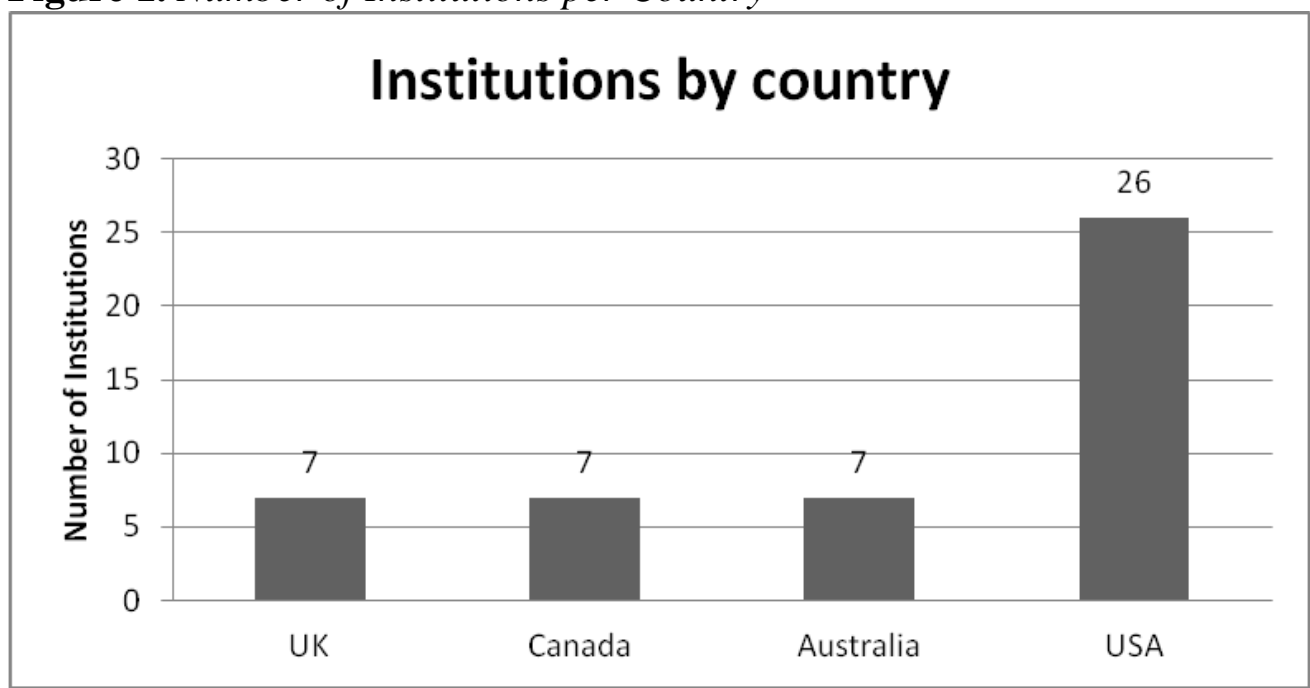

Source: QS (2013).

The proportion of the sample in each ranking category is illustrated by the Figure 2.

Figure 2. Number of Institutions per Ranking Bracket

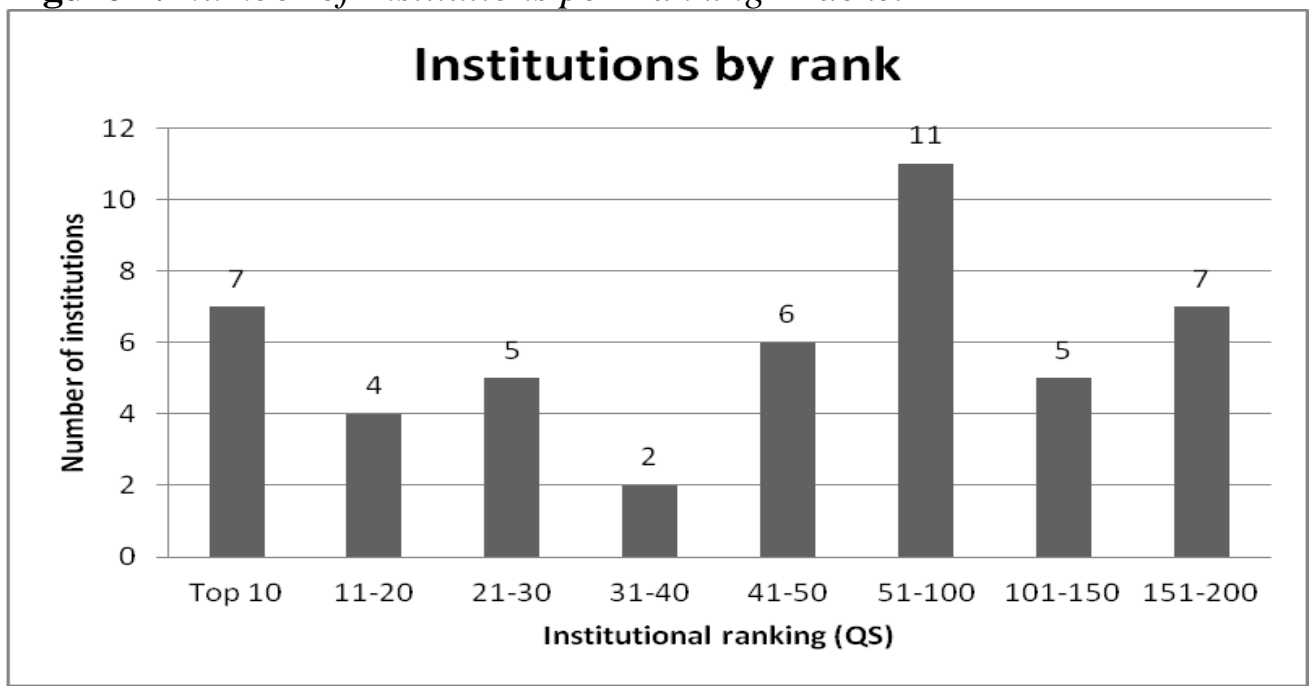

Source: QS (2013).

\section{Data Collection - Syllabus Analysis}

Once the institutions had been identified an analysis of the modules offered was required. The information required for each module (descriptor) was accessed entirely via the individual department's website which is available from the parent institutions website ${ }^{6}$.

\footnotetext{
${ }^{6}$ This methodology is similar to that of Cornelius et al. (2007) who also utilised a recognised ranking system to select her sample of institutions, followed by a content and statistical analysis of the institutions websites.
} 
Many of the institutions offered a vast number of modules to final year students. For example, including elective modules, Newcastle University (2013) offered a total of nineteen options for final year students. Due to the differing number of modules offered and the considerable time requirements for analysing each modules content a total of ten final year modules were analysed per institution. In order to select ten modules, the offered module titles were listed alphabetically, assigned a chronological numerical value and selected with the use of a random number generator (Randomness and Integrity Service LTD 2014 ${ }^{7}$ ).

Following the identification of modules for analysis a content analysis of the module descriptors was performed using mixed qualitative and quantitative methods. The content analysis comprises of the identification of and the frequency of keyword occurrence; in order to select relevant keywords all of the syllabuses were read in detail prior to the analysis following which a keyword list was created. Keywords consisted of words related to CSR and ethics, a full list of 36 words/phrases was created which included words such as ethical, sustainable and responsibility.

Each module for each institution received a score relating to the number of keyword hits (frequency of occurrence); the score for each module was combined to provide a total score for each institutions syllabus. This score was weighted to control for the influence of differing syllabus lengths i.e., total number of words/number of hits, giving the number of words per hit.

\section{Statistical Analysis-Techniques Used}

Once the influence of syllabus length had been controlled for, in order to test for differences in CSR and ethics inclusion in syllabuses in each of the countries (Hypothesis 1) a one way ANOVA (analysis of variance) among groups was conducted. The analysis preliminarily tested that the assumption of homogeneity of variance was not violated prior to recording the results.

With regards to Hypothesis 2 and the effect of institutional ranking on ethics and CSR inclusion an independent sample $t$-test was conducted.

\section{Results}

\section{Hypothesis 1: Effect of Geographical Location}

A one-way among groups analysis of variance was conducted to analyse the impact of country on the levels of ethics teaching as measured by a content analysis of the institutions syllabuses. There was no statistically significant difference among the groups $(\mathrm{P}>0.05)$ in terms of ethics inclusion in the institutions syllabuses $[\mathrm{F}(3,43)=837)]$.

\footnotetext{
${ }^{7}$ This service provided by Randomness and Integrity Service LTD is also utilised for other scientific studies, drawing lotteries and by online casinos.
} 
Table 2. CSR and Ethics Inclusion per Country-Words per Hit

\begin{tabular}{|l|c|c|c|}
\hline Country & $\begin{array}{c}\text { Number of } \\
\text { institutions }\end{array}$ & $\begin{array}{c}\text { Mean-Number of } \\
\text { words per hit* }\end{array}$ & $\begin{array}{c}\text { Standard } \\
\text { deviation }\end{array}$ \\
\hline UK & 7 & 23.6 & 6.1 \\
\hline Canada & 7 & 25.5 & 4.6 \\
\hline Australia & 7 & 34.5 & 3.7 \\
\hline USA & 26 & 33.4 & 4.4 \\
\hline
\end{tabular}

Note: * Number of words per hit, i.e. words per reference to CSR and ethics inclusion as per the list of key word/phrase occurrence.

Source: Authors' estimations.

\section{Hypothesis 2: Effect of Institutional Ranking}

An independent sample $t$-test was conducted to compare the ethics inclusion in syllabuses for universities in the top 50 and the bottom 100 universities. There was no significant difference in scores for top 50 universities $(\mathrm{M}=37.26, \mathrm{SD}=21.84)$ and bottom 100 universities $[\mathrm{M}=29.83$, $\mathrm{SD}=11.76), t(29)=0.858, \mathrm{p}=0.39$ ] (Table 2).

\section{Discussion}

By focusing on the agricultural industry this paper extends the literary coverage on the subject of CSR and ethics by analysing a key primary industry. The paper also offers further insights into the role that universities play in the provision of CSR and ethics teaching.

The methodologies used were similar to those previously utilised to analyse business schools by Cornelius et al. (2007) and also drew upon cross disciplinary comparisons from papers including Dunfee and Robertson (1988), Vallario (2010) and Rossouw (2002). Due to the comparative lack of directly linkable literature such cross disciplinary comparisons were inherently necessary.

The primary aim of this paper is not to give a definitive and all encompassing analysis of CSR/ethics in agriculture and its provision in agricultural schools; rather the aim of this paper is to provide an initial insight into a divergent area of ethical analysis. The paper has the potential to highlight the benefits and arguably the necessity for closer evaluation of CSR and ethics provision in institutions, training persons in a number of industries. Utilising the same model it is entirely possible to conduct analyses in a range of industries.

\section{International Disparities}

Whilst the expected differences among countries as hypothesized by hypothesis one were not found $(\mathrm{P}>0.05)$ there remains considerable scope for the analysis of ethics teaching methods in each of the countries. 
The relatively small sample size may have hindered the finding of significant results. Given that the sample represents the entirety of the suitable institutions in these countries it may be necessary to incorporate either additional years of syllabus or to broaden the analysis to encompass other fields, e.g. environmental science. Another interesting avenue for future analysis is the potential to further the depth of the analysis by attempting to discern between the types of ethics provided, i.e. proactive vs. reactive ethics (Cornelius et al. 2007).

While not covered in this paper it is also worth considering the antecedents of the public's ethical standing regarding their food purchasing habits and how this may affect the corporate and academic world.

\section{Effect of Ranking}

The analysis found no significant $(\mathrm{P}>0.05)$ relationship between ranking and inclusion of CSR and ethics teaching. This is surprising given the ethical development of a practitioner can affect their effectiveness within an organisation (Rossouw 2002). However, the analysis made no differentiation between the forms of ethics present in the syllabuses. As aforementioned, Cornelius et al. (2007) describes two forms of ethics: proactive and reactive ethics. Proactive ethics is related to the embracing of ethically and socially responsible thinking; whereas, reactive ethics relates to the response to legal and regulatory requirements (Cornelius et al. 2007). Cornelius et al. (2007) found that higher ranked MBA programs had a higher level of proactive ethics incorporation than their lower ranked counterparts who were more likely to incorporate reactive ethics. It is possible that re-formulation of the analysis to distinguish between proactive and reactive ethics could yield different results with regard to the effect of ranking.

Gray and Balmer (1998), Fombrun and Shanley (1990) and Roussow (2002) suggest, CSR and ethical standing can act as a key competitive advantage, enabling practitioners to redesign organisational practices using moral imagination. Thus, for creating an enhanced corporate reputation (Rossouw 2002), the formulation and inclusion of a CSR and ethics rating could and should be included into ranking criteria for institutions. It has the potential to benefit students, universities, industries and indeed the public at large. However, there remains a requirement for further analysis of ethics, content and the type of ethics inclusion, prior to the development of such a ranking parameter. See Moon (2015) for a discussion of learning from the ranking of HEIs in general, e.g. Pinstripes and the Green Planet Index.

\section{Future Research Opportunities}

The paper has answered a number of questions discovering several significant findings. However, in doing so it has also raised a number of new 
questions which require investigation to gain further understanding of the ethical foundations of the industry.

The first and perhaps the most interesting area for future research is further analysis of the differences among countries and the factors which give rise to the causes of those differences. Developing an understanding of the antecedents of differences among countries has the potential to enable business, universities and policy makers alike to further the ethical standing of the industry. As Vallario (2010) indicates, furthering this ethical standing has the potential to yield social, environmental and economic returns.

Secondly, if indeed universities can equip students to become more morally imaginative, then they also better equip them to generate value in the companies in which they work (Rossouw 2002). This in turn can only benefit the institutions reputation and position in the rankings. Therefore, it is reasonable to suggest that future research should seek to further investigate the role of schools in the provision of CSR and ethics teaching (in a number of fields); with the premise that a CSR and ethics score eventually be a consideration in ranking the institutions in question.

\section{Limitations}

This paper whilst providing a number of relevant and interesting results is not without its limitations. Firstly, and most notably the paper is potentially limited in its scope of applicability due to the fact that the focus is on a singular industry and a singular course per university. The findings of the analyses may well be relevant to other industries (particularly primary industries) and courses but the individual analysis of other industries/courses would be required in order to determine this.

The second major limitation of the study is that the sample only analyses four countries ${ }^{8}$, all of which are English speaking (or in Canada's case predominantly English speaking). To facilitate greater comprehensiveness, analysis of other nations and institutions would be necessary although there are evidently a number of practical issues with such an analysis.

Thirdly, there is considerable potential to expand on the scope of Table 2 in order to facilitate a more accurate analysis of the policy and legislative differences among countries. Although, given the function of the Table 2 was only to illustrate that there exist differences in a few key areas, the limited range of the variables compared should be of little significance.

Finally, the study does not distinguish between proactive and reactive ethics as described by Cornelius et al. (2007). Further analysis of the variety of the ethics content within the syllabuses would make for more concrete identification of institutions with higher or at least more beneficial ethical provision.

\footnotetext{
${ }^{8}$ With the exceptions of University College Dublin (Ireland) and Massey University (New Zealand).
} 


\section{Conclusions}

CSR and ethics is a burgeoning area of research and has attracted considerable interest in both the academic and corporate worlds in recent years. This however, would appear to be the first study of its kind to specifically focus on the CSR and ethical components of agricultural education.

The need for businesses to develop ethical standards over and above legislative minimums is clear. Universities should seek to equip students with good ethical reasoning skills which will enable them to develop ethically sound business practices in their future careers. Despite this, surprisingly, there appears to be little correlation between the ranking of the institutions and the level of CSR and ethics provided. There is a need to consider whether the addition of a CSR and ethics score to the ranking criteria of institutions would be to the benefit of students and businesses alike. Particularly, given that the areas are of considerable interest to both the public (Wilson 2000) and businesses (Zairi and Peters 2002, Fombrun and Shanley 1990). Furthering the understanding of the antecedents of the industries ethical positioning enables businesses and universities alike to become better equipped to respond to the changing dynamics of the industry.

The universities have the potential to instil a greater understanding of the ethical foundations of the industry into their students. This can facilitate a greater understanding of the public's concerns and standings with regard to the industry and enable a move away from defensive arguments based on the paradigm of production (Zimdahl 2000).

This study has provided an initial insight into a new and interesting avenue for research which has the potential for widespread academic, corporate and environmental benefits. Future research opportunities are numerous and interesting perhaps none more so than the analysis of the ethical stance of the public with regard to the agricultural industry.

\section{References}

American Meat Institute (2009) EPA: cattle material prohibited in animal feed not hazardous waste. Washington DC, USA: American Meat Institute. Retrieved from https://goo.gl/Jekrr0.

Canadian Federal Department of Health (2012) Drugs and health products-hormonal growth promoters. Ottawa, Canada: Canadian Federal Department of Health.

Canadian Federation of Agriculture/Federation Canadienne de L'Agriculture (CFA) (2007) A Canadian farm bill-a new vision for Canadian agriculture. Ottawa, Canada: Government of Canada-CFA. Retrieved from http://goo.gl/K7ykgv.

Canadian Food Inspection Agency (CFIA) (2013) Information for the publicbiotechnology and the environment. Government of Canada. Retrieved from http://goo.gl/Kt49BH. [Acessed: 9 January 2014]

Cornelius N, Wallace J, Tassabehji R (2007) An analysis of corporate social responsibility, corporate identity and ethics teaching in business schools. Journal of Business Ethics 76(1): 117-135.

Department for Environment Food and Rural Affairs (DEFRA) (2013a) 2010-2015 
government food policy: food and farming industry. London, UK: Department for Environment Food and Rural Affairs. Retrieved from https:/goo.gl/xeuIZD. [Accessed: 6 January 2014]

Department for Environment Food and Rural Affairs (2013b) Fallen stock: safe disposal. London, UK: Department for Environment Food and Rural Affairs. Retrieved from https://goo.gl/v9eoiA.

Department of Agriculture (2013) Agriculture and food. Canberra: Australian Government. Retrieved from http://goo.gl/2leAGY.

Department of the Environment (2013a) Water quality in Australia. Canberra: Australian Government. Retrieved from http://goo.gl/mkkwb8. [Accessed: 20 December 2013]

Department of the Environment (2013b) Salinity. Canberra: Australian Government. Retrieved from http://goo.gl/nYjGbG.

Diebel P (2008) Ethics and Agriculture: A teaching perspective. Journal of Agricultural and Resource Economics 33(3): 303-310.

Dunfee TW, Robertson DC (1988) Integrating ethics into the business school curriculum. Journal of Business Ethics 7(11): 847-859.

Eurpoean Environment Agency (2010) Land use-SOER 2010 thematic assessment. Copenhagen, Denmark: European Environment Agency. Retrieved from http://goo.gl/FvGbW7. [Accessed: 6 January 2014]

Foley JA, Costa MH, Delire C, Ramankutty N, Snyder P (2003) Green surprise? How terrestrial ecosystems could affect earth's climate. Frontiers in Ecology and the Environment, 1(1): 38-44.

Fombrun C, Shanley M (1990) What's in a name? Reputation building and corporate strategy. Academy of Management 33(2): 233-258.

Food Standards Australia and New Zealand (2011) Food issues-hormonal growth promotants in beef. Canberra \& Wellington. Retrieved from http://goo.gl/eR5dsr. [Accessed: 19 December 2013]

Goodman AM (2012) The impacts of altered water and salinity regime on the condition of wetlands in the upper south east of South Australia. Adelaide, Australia: School of Earth and Environmental Sciences and the School of Civil, Environmental and Mining Engineering, Adelaide University. Retrieved from https:/goo.gl/NmAhyV. [Accessed: 7 January 2014]

Government of Canada (2010) Water pollution control. Ottawa, Canada: Government of Canada. Retrieved from http://goo.gl/twxvPb. [Accessed: 6 January 2014]

Gray ER, Balmer JMT (1998) Managing corporate image and corporate reputation. Long Range Planning 31(5): 695-702.

Gwyther CL, Williams PA, Golyshin PN, Edwards-Jones G, Jones DL (2011) The environmental and biosecurity characteristics of livestock carcass disposal. Waste Management 31(4): 767-778.

Hendrickson MK, Harvey, SJJR (2005)The ethics of constrained choice: how the industrialisation of agriculture impacts farming and farmer behaviour. Journal of Agricultural and Environmental Ethics18(3): 269-291.

House of Commons Environment, Food and Rural Affairs Committee (HCEFRA) (2012) Greening the common agricultural policy. London: HCEFRA. Retrieved from http://goo.gl/6kggpH. [Accessed: 18 December 2013]

Lozano FJ, Palau-Salvador G, Gozalvez V, Boni A (2006) The use of moral dilemmas for teaching agricultural engineers. Science and Engineering Ethics 12(2): 327-334.

McEachern MG, Schroder JA (2001) The role of livestock production ethics in consumer values towards meat. Journal of Agricultural and Environmental Ethics 15(1): 221 237.

Ministry of Agriculture and Food (2009) Deadstock disposal options for on farm. Ontario, Canada. Retrieved from http://goo.gl/hYyTpl. [Accessed 7 January 2014]

Moon CJ, Bonny C (2001) Business ethics(ed.): The Economist Books. Retrieved from 
http://goo.gl/T3jc5q. [Accessed: 20 June 2015]

Moon CJ (2015) Green universities and eco-friendly learning: from league tables to ecoentrepreneurship education. ECIE Conference Paper 2015. Retrieved from http://goo.gl/FYVqAq. [Accessed: 20 June 2015]

Newcastle University (2013) BSc agriculture-module list. Newcastle, UK: Newcastle University. Retrieved from http://goo.gl/tr3Arh.

Nguyen N, Leblanc G (2001). Corporate image and corporate reputation in customers' retention decisions in services. Journal of Retailing and Consumer Services 8(4): 227-236.

Organisation for Economic Co-operation and Development (OECD) (2011). Evaluation of agricultural policy reforms in the United States. Paris, France: OECD. Retrieved from http://goo.gl/VpBcFC. [Accessed: 8 January 2014]

Porter ME, Kramer MR (2011) Creating shared value. The Harvard Business Review (89) 2011 (January-February): pages 1-2.

Qaim M, Kouser S (2013) Genetically modified crops and food security. Department of Agricultural Economics and Rural Development and Institute of Agricultural and Resource Economics 8(6): e64879.

QS-Quacquarelli Symonds (2013) QS World university rankings by subject 2013. London, UK: Quacquarelli Symonds (QS). Retrieved from http://goo.gl/o7W3zf. [Accessed: 9 January 2014]

Randomness and Integrity Service LTD (2014) Random number generator. Dublin, Ireland: Randomness and Integrity Service LTD. Retrieved from https://goo.gl/ bm6kZ.

Rossouw G (2002) Three approaches to teaching business ethics. Teaching Business Ethics 6(4): 411-433.

Sagoff M (1988) On teaching a course on ethics, agriculture and the environment. Journal of Agricultural Ethics1(1): 69-84.

Thompson P (2000) Food and agricultural biotechnology: incorporating ethical considerations. Ottawa, Canada: The Canadian Biotechnology Advisory Committee. Retrieved from https://goo.gl/RR19qP. [Accessed: 6 January 2014]

United States Government Printing Office (2014) Implantation or injectable dosage form new animal drugs. Washington DC, USA: United States Government Printing Office. Retrieved from https://goo.gl/Qc9q91: part-522.

Vallario C (2010) The role business schools play in promoting corporate social reponsibility. Financial Executive 26(6): 52-55.

Wilson I (2000) The new rules: ethics, social responsibility and strategy. Strategy \& Leadership 28(3): 12-16.

Zairi M, Peters J (2002) The impact of social responsiblity on business performance. Managerial Auditing Journal 17(4): 174-178.

Zimdahl R (2000) Teaching agricultural ethics. Journal of Agricultural \& Environmental Ethics13(3): 229-247. 
